\title{
Human capital of Arctic Yakutia as a resource of ethnic group resilience
}

\author{
Sargylana Baisheva ${ }^{1, *}$ \\ ${ }^{1}$ Institute for Humanities Research and Indigenous Studies of the North SB RAS, Center for Ethno-sociological Research, 1, \\ Petrovskogo str., Yakutsk, 677000, Russia
}

\begin{abstract}
In the Strategy of the Arctic zone of the Republic of Sakha (Yakutia) for the period up to 2035, an important role is given to human resources in the industrial development of the region. It was found that a whole range of factors influences the formation and use of human resources. These are an unfavorable demographic situation, migration processes associated with the outflow of the able-bodied population, a low standard of living, an unsatisfactory state of social infrastructure, transport inaccessibility, poor efficiency of public administration and impact on the development of territories inhabited by small people ethnic groups. As a result of our research, we identified indicators of a sociological assessment of labor adaptation of the economically active population and the main trends in employment against the background of problems of stability and vulnerability of indigenous communities. In general, the absence of a systematic, complex interaction between government bodies, local governments, the business community and the population itself complicates the sustainable development of the Arctic regions in the future. For the further development of the Arctic, special attention should be paid to the adaptation strategies of the aboriginal community, taking into account the personal resource.
\end{abstract}

\section{Introduction}

A focus should be shifted to integrated studies of indigenous peoples of the North that experience a complex period of transformation under conditions of new social challenges put forward by globalization.

Current ethno-social processes in the region characterized by dynamic social environment, imperfection of the legal regulation in traditional economic sectors of the North, the interrelation between political socio-economic, environmental factors complicate the everyday life of people in the Arctic region.

Large-scale capital projects aimed at improving quality of life of indigenous peoples in the Arctic have attracted genuine interest of the scientific community. Regional issues and perspectives of human development in the Arctic have been the focus of studies in Yakutia, Russia, and abroad [1, 2, 3, 4].

In general, employment and human resources is a multifaceted problem addressed by the Russian Academy of Sciences as well as its Siberian Branch within the context of ongoing social changes, including the demographic aspect, resilience of Arctic communities, the level of education, human health, gender relations, etc.

A number of collaborative studies and individual papers analyse the overall dynamics of modern Russian society and transformation processes under market conditions affecting employment patterns, all aspects of employer-worker relationship, the state of social classes, social groups, and strata both at a national and regional scale $[5,6,7]$.

The labour market as a basic concept for any region has been paid great attention in sociology, political science, and regional studies. Interesting methods are suggested by the Institute of Regional Consulting led by A. N. Pilyasov that develops documentation for strategic policy in socio-economic development of federal subjects of the Russian Federation as well as municipalities; provides scientific, analytical, and methodological support for strategic socio-economic development of the Arctic zone of the Russian Federation and the Far North regions [8, 9].

The Arctic is viewed as a constant instable, fragile and mobile challenge to Russia that motivates to find new adjusted institutions, forms, techniques, relations and encourages innovative search.

By and large, the literature review shows that Arctic Yakutia has no unified paradigm for innovative search to develop local communities as the development of labour migration, local identity, infrastructure mega-projects and business structures, institutional factors of regional development, the design of strategies and programs for socio-economic development of regions and municipalities are poorly understood.

Most experts agree that traditional practices on ancestral lands is not only the basis of indigenous livelihood but a lifestyle integral to traditional culture

* Corresponding author: baisargy09@yandex.ru 
and worldview of Northern ethnicities as a whole [10, $11]$.

\section{Results}

Table 1. Population dynamics in the areas traditionally inhabited by minor indigenous peoples of the North in the Republic of Sakha (Yakutia) for 1989-2018, persons.

\begin{tabular}{|c|c|c|c|c|}
\hline \multirow[b]{2}{*}{ Municipal districts } & \multicolumn{2}{|c|}{ Census 1989* } & \multirow{2}{*}{$\begin{array}{l}\text { average } \\
\text { for } \\
2013- \\
2017 \\
* * \\
\end{array}$} & \multirow[b]{2}{*}{$\begin{array}{c}\text { for } \\
01.01 \text {. } \\
2018^{* *}\end{array}$} \\
\hline & $\begin{array}{l}\text { Total } \\
\text { popu- } \\
\text { lation }\end{array}$ & $\begin{array}{c}\text { Indi- } \\
\text { genous } \\
\text { popu- } \\
\text { lation }\end{array}$ & & \\
\hline Total in the republic & $\begin{array}{c}1094 \\
065\end{array}$ & 24674 & $\begin{array}{l}957 \\
961\end{array}$ & $\begin{array}{l}964 \\
330\end{array}$ \\
\hline $\begin{array}{l}\text { In the areas } \\
\text { traditionally inhabited } \\
\text { by minor indigenous } \\
\text { peoples of the North in } \\
\text { RS(Y) }\end{array}$ & $\begin{array}{c}48 \\
416\end{array}$ & 18682 & 42469 & 42121 \\
\hline Share in $R S(Y), \%$ & 4.4 & 75.7 & 4.4 & 4.4 \\
\hline 1. Abyysky & 572 & 88 & 489 & 479 \\
\hline 2. Aldansky & 2323 & 1551 & 2296 & 2268 \\
\hline 3. Allaykhovsky & 1435 & 401 & 618 & 631 \\
\hline 4. Anabarsky & 2776 & 805 & 3425 & 3567 \\
\hline 5. Bulunsky & 5326 & 2417 & 3833 & 3792 \\
\hline 6. Verkhne-Kolymsky & 811 & 266 & 1124 & 1097 \\
\hline 7. Verkhoyansky & $* * *_{-}$ & $* * *_{-}$ & 979 & 984 \\
\hline 8. Zhigansky & 6005 & 1977 & 4255 & 4222 \\
\hline 9. Kobyaysky & 1267 & 587 & 1135 & 1109 \\
\hline 10. Mirninsky & 344 & 170 & 286 & 271 \\
\hline 11. Momsky & 1496 & 479 & 4078 & 3949 \\
\hline 12. Neryungrinsky & 1479 & 796 & 1033 & 971 \\
\hline 13. Nizhne-Kolymsky & 2160 & 1160 & 1771 & 1731 \\
\hline 14. Oymyakonsky & 2265 & 311 & 1736 & 1739 \\
\hline 15. Olekminsky & 2375 & 733 & 2345 & 2317 \\
\hline 16. Oleneksky & 4140 & 2310 & 3994 & 4072 \\
\hline 17. Sredne-Kolymasky & 344 & 290 & 316 & 310 \\
\hline 18. Tomponsky & 1279 & 707 & 890 & 909 \\
\hline 19. Ust-Maysky & 5239 & 1829 & 1719 & 1665 \\
\hline 20. Ust-Yansky & 4198 & 863 & 3357 & 3225 \\
\hline 21. Eveno-Bytantaysky & 2582 & 942 & 2790 & 2813 \\
\hline
\end{tabular}

*Minor indigenous peoples of the North in $R S(Y), 9-10$ (Poligraphist, 1994). **Socio-economic status of the areas of traditional habitat and economy of minor indigenous peoples of RF on the territory of RS(AY) for 2012-2017, Statistics 17/466-dsp, 6-8 (2018). ***Verkhoyansky District was not listed as an area of habitat of indigenous peoples of the North in 1989.

More than $65 \%$ of indigenous peoples of the North in Russia live in rural areas where ancestral traditions and lifestyle are very carefully preserved. 82.5 thousand indigenous people were recorded in the Arctic zone of the Russian Federation by the 2010 Russian population and housing census.

It is noteworthy that the share of indigenous peoples of the North in the population of the Sakha Republic (Yakutia) by ethnic group increased from $2.2 \%$ in 1989 to $4.2 \%$ in 2010.

In administrative composition 71 rural settlements in 21 districts (uluses) are recorded as areas of traditional habitat and traditional economic activities of indigenous peoples of the North of the Sakha Republic (Yakutia). They include 48 ethnic (nomadic) rural administrative divisions (naslegs).

As of January 1, 2018 the population of 42.1 thousand ( $4.4 \%$ of the population of Yakutia), mostly persons of indigenous ancestry (minor indigenous peoples of Russia), was recorded there (Table 1).

The area inhabited by indigenous peoples of the North extends over a vast territory that is a home to 75.7 $\%$ of Republic's indigenous ethnic groups [12].

The Arctic zone conditionally includes 13 districts with 30.9 thousand people in 49 localities of traditional settlement of indigenous peoples, among them 5 districts of the Arctic coast with 12.9 thousand in 23 settlements, and northern territories not included into the Arctic zone as they are located at less high latitudes but still established the areas of the Far North ( 8 districts with 11.2 thousand people in 22 settlements).

Of particular interest for researchers is the Arctic zone including the Arctic coast as the most remote and poorly studied subregions of Yakutia with the most extreme conditions inhabited by indigenous peoples of the North.

The Arctic community has exhibited resilience in the face of changes with profound shifts in natural (climate), cultural (including language), and economic (emergence of mixed economy) processes. Most attention is paid to the analysis of institutional aspects of employment, including legislation, interaction between communities of descent and industrial business structures. Monitoring of indices to track changes in a society in the center of which is the man in the Arctic is a concrete step towards identifying priorities in further development of Arctic territories.

The key feature of the area under discussion where localities of settlement of indigenous peoples are concentrated that determines specific approaches to its socio-economic development and national security is high sensitivity of traditional lifestyle of persons of indigenous ancestry to external effects.

Major risks of vulnerability for economic activities of minor indigenous peoples of the North and the Arctic are a complex transportation scheme and a lack of yearround land transport; poor equipment and low staff capacity of educational institutions in the areas inhabited by minor indigenous peoples; underdeveloped social and productive infrastructure, high rate of thermal and electric energy losses, deterioration of infrastructure facilities and the increasing rate of dilapidated housing; low quality and slow mobile phone and internet service in majority of areas where minor indigenous peoples live. All risks mentioned above complicate everyday life of minor indigenous peoples of the North, being a 
cost-increasing factor in end-product value that is multiple times higher than the average in the Republic, and lead to lower quality of education.

Despite state support for education the problems of human (professional) resources in sectors of industry still remain unsolved in areas traditionally inhabited by minor indigenous peoples of the North. $50 \%$ of schools in the Arctic are small with lower capacity, poor infrastructure and lack of qualified staff. $88 \%$ of school graduates from Arctic districts in 2018/2019 academic year were admitted to institutions of vocational and higher education which shows their motivation to continue education. $90 \%$ of the admitted students were provided with dormitory by the educational institution. From 2014 to 2019, 5 secondary schools with 965 student capacity, 16 pre-school institutions with 901 places were built.

At beginning of year 2018, the number of people employed in major industrial sectors in the areas inhabited by minor indigenous peoples of the North of the Sakha Republic including small businesses was as low as 13.4 thousand people including 5.0 thousand in the productive and 8.4 thousand in non-productive sectors [12].

Thus, every fifth inhabitant in places of residence of minor indigenous peoples of the North is employed in the non-productive (public) sector, with only every eighth being employed in the productive sector including mining (every 20th), agriculture (every 25th), and energy (every 43rd).

Surveys that we conducted show that indigenous people living in ancestral lands hope for improvement of life in the Arctic and in the North following not only traditional lifestyle but mostly industrial development and future infrastructure projects.

However, despite the measures taken, the situation of minor indigenous peoples of the North has been compounded by inadaptability of their traditional lifestyle to the modern economic situation in recent decades. The number of people employed in reindeer herding has been declining in the Republic of Sakha (Yakutia) since 2010 (Table 2).

Low competitiveness of traditional economic activities is related to low production, higher transportation cost, lack of modern factories and technologies for complex processing of raw materials and biological resources.

In this way, the steepest decline in employment rates in $2010-2017$ of $8.7 \%$ is found in the Arctic districts (Ust-Yansky, Anabarsky, Verkhne-Kolymsky, Srednekolymsky). Generally, the highest unemployment rate was in 2016 - 2017 in the Eveno-Bytantaysky and Kobyaysky districts $13.2 \%$ as compared to $7.2-6.9 \%$ in the Sakha Republic. The highest stress index in the labour market recorded in the Oleneksky district with $61.7-35.8$ person per one vacancy as compared to $1.5-$ 3.0 for the Sakha Republic.

For a number of years we have conducted sociological (field) surveys in areas inhabited by minor indigenous peoples of the North, including the Neryungrinsky and Aldansky districts (towns Aldan, Neryungri, villages Khatystyr, Iengra in 2010 - 2014 and
2017 - 2019), the Allaykhovsky district (Olenogorsk, Russkoe Ustye in 2011 and 2014), the Oleneksky district (2006).

Table 2. Population engaged in reindeer herding in the areas of traditional habitat of minor indigenous peoples of the North in the Republic of Sakha(Yakutia) for 2010-2018*.

\begin{tabular}{|l|c|c|c|c|c|}
\hline & $\mathbf{2 0 1 0}$ & $\mathbf{2 0 1 5}$ & $\mathbf{2 0 1 6}$ & $\mathbf{2 0 1 7}$ & $\mathbf{2 0 1 8}$ \\
\hline Total in RS(Y) & $\mathbf{2 1 5 7}$ & $\mathbf{2 0 0 9}$ & $\mathbf{1 8 4 2}$ & $\mathbf{1 7 9 2}$ & $\mathbf{1 4 9 0}$ \\
\hline RS(Y), \% & $\mathbf{1 0 0 , 0}$ & $\mathbf{1 0 0 , 0}$ & $\mathbf{1 0 0 , 0}$ & $\mathbf{1 0 0 , 0}$ & $\mathbf{1 0 0 , 0}$ \\
\hline Arctic zone & $\mathbf{1 3 1 4}$ & $\mathbf{1 1 4 5}$ & $\mathbf{1 0 5 3}$ & $\mathbf{1 1 0 7}$ & $\mathbf{9 5 1}$ \\
\hline $\begin{array}{l}\text { share in } R S(Y), \\
\%\end{array}$ & $\mathbf{6 0 . 9}$ & $\mathbf{5 7 . 0}$ & $\mathbf{5 7 . 2}$ & $\mathbf{6 1 . 8}$ & $\mathbf{6 3 . 8}$ \\
\hline Abyysky & 8 & 7 & 6 & 6 & 0 \\
\hline Allaykhovsky & 20 & 6 & 0 & 0 & 0 \\
\hline Anabarsky & 98 & 98 & 97 & 109 & 112 \\
\hline Bulunsky & 133 & 115 & 129 & 163 & 150 \\
\hline $\begin{array}{l}\text { Verkhne- } \\
\text { Kolymsky }\end{array}$ & 19 & 13 & 13 & 13 & 14 \\
\hline Verkhoyansky & 74 & 40 & 48 & 48 & 22 \\
\hline Zhigansky & 111 & 76 & 75 & 76 & 75 \\
\hline Momsky & 215 & 118 & 142 & 140 & 96 \\
\hline $\begin{array}{l}\text { Nizhne- } \\
\text { Kolymsky }\end{array}$ & 172 & 216 & 162 & 162 & 112 \\
\hline Oleneksky & 52 & 54 & 65 & 65 & 65 \\
\hline Srednekolymsky & 61 & 40 & 37 & 28 & 28 \\
\hline Ust-Yansky & 143 & 205 & 170 & 169 & 142 \\
\hline $\begin{array}{l}\text { Eveno- } \\
\text { Bytantaysky }\end{array}$ & 208 & 157 & 109 & 128 & 135 \\
\hline $\begin{array}{l}\text { Non-Arctic } \\
\text { districts }\end{array}$ & $\mathbf{8 4 3}$ & $\mathbf{8 6 4}$ & $\mathbf{7 8 9}$ & $\mathbf{6 8 5}$ & $\mathbf{5 3 9}$ \\
\hline $\begin{array}{l}\text { share in RS(Y), } \\
\%\end{array}$ & $\mathbf{3 9 . 1}$ & $\mathbf{4 3 . 0}$ & $\mathbf{4 2 . 8}$ & $\mathbf{3 8 . 2}$ & $\mathbf{3 6 . 2}$ \\
\hline Aldansky & 267 & 260 & 160 & 150 & 140 \\
\hline Kobyaysky & 148 & 118 & 130 & 93 & 83 \\
\hline Neryungrinsky & 165 & 156 & 156 & 143 & 94 \\
\hline Oymyakonsky & 63 & 65 & 57 & 69 & 56 \\
\hline Olekminsky & 14 & 117 & 111 & 116 & 71 \\
\hline Tomponsky & 157 & 132 & 108 & 109 & 65 \\
\hline Ust-Maysky & 17 & 6 & 5 & 9 & 9 \\
\hline
\end{tabular}

* Ministry of Agriculture of the Republic of Sakha (Yakutia)

We used questionnaire, interview of experts, nonstandardized observation of changes in social reality (transformation of labour market and employment). Interviewed experts included representatives of the legislature and the executive, large and medium business, entrepreneurs, managers of industrial enterprises, educational institutions, representatives of non-governmental structures and native population including indigenous leaders.

We used snowball sampling to study labour issues at the new stage of industrial development of the territory (30 informants) as well as employment and vocational 
needs (50 informants). The first survey included informants under $30(20 \%), 30-40(40 \%), 40-50$ (7 $\%), 50-60(13 \%)$, above $60(20 \%)$ years of age. Among them state employees made up $80 \%$, private companies $20 \%$; $67 \%$ are married; $93 \%$ have higher education; top managers comprise $13 \%$, managers $20 \%$, professional workers $20 \%$, managerial workers $47 \%$; $73 \%$ have average income, $27 \%$ below the average.

We used convenience sampling to interview informants on problems of development of small business (34 informants), opinion of entrepreneurs about the role of local authorities in their area of activity (52 entrepreneurs).

The quality of labour resources is affected by complications in the supply of industrial enterprises by highly qualified professionals from local population (low qualification, poor work skills of indigenous people in industrial sectors), the level of social and productive infrastructure, less opportunities for self-fulfilment, constant migration, long-term unemployment.

Interviewing administrators of educational institutions showed challenges in the system of search and selection of young professionals among graduates of educational institutions of higher education (branch of the Northeastern Federal University, Yakutsk) whose tuition fees were covered from the Republic's budget; complications in building local workforce and further recruiting local professionals in large industrial enterprises.

Lately, the M. K. Ammosov Northeastern Federal University (Yakutsk) and certain industrial enterprises have agreed on federal government funded quotas in technical disciplines. The issues of recruitment and long-term employment of local workforce at industrial enterprises operating in Yakutia have also been addressed. There is a strong need to build a vocational education cluster involving experts from large mining companies active in the region such as PJSC Gazprom, OJSC Surgutneftegas, PJSC Rosneft, PLC TransneftVostok.

Monitoring of major indices of the labour market in Yakutia based on survey data of the regional labour market, state statistical survey, and employment services revealed inadequate regulating effect of employment policy on the state of labour market.

Major factors impeding the job placement are partial disparity between educational institutions and the labour market; poor awareness of young people about their rights; the gap between expectation and demands of population and the reality of the labour market, persistence of old stereotypes among employers about young people not being able to prove oneself, build working relationships in a team, being too emotional.

The most important quality for employment is considered to be professionalism, commitment, and leadership. The survey showed that better quality of work life depends on job satisfaction, salary increments, moral or material rewards for work, the quality of social and labour relations (first of all, social and psychological environment in the workplace).

The informants of the survey answered affirmatively on the statements that work is "a means of personal gain for company owners" (53.3\%); "an important way to find and develop one's abilities, their personal potential" $(33.3 \%)$; "an activity respected by society", "foundation for team building than becomes valuable for its members", "a means to satisfy a man's need to be a useful member of society", "the main way to meet the needs of society for certain goods and services" (26.7\% each); "a basis for one's credibility among family and friends" (21.4\%); "a basis for professional development and promotion", "a means of self-determination and selfaffirmation in society", "a basis for secure position and confidence in the future", "a means to satisfy one's need for the meaning of life" (20.0\% each); "a reliable source of material well-being" (13.3\%); "a source of joy and moral satisfaction for employees" $(6.7 \%) .40 .0 \%$ of informants provided a negative response to the statements, 33.3 to $78.6 \%$ partially agreed.

\section{Conclusions}

Despite the region's remoteness from centers of civilization, minor indigenous peoples of the North and the Arctic remain in the focus of world community and science and are involved in globalization processes.

Everyday life of indigenous ethnic groups is a great example of resilience, engagement in traditional economic activity on vast territories, and the ability to adapt to severe natural reality and survive under impact of industry on their native habitat.

Rapid development of technologies, their integration into many spheres of social life affected the aboriginal community of Yakutia as well. In its progress the aboriginal community goes through a complicated process of adaptation to current transformations through breaking stereotypes and changing the socio-cultural paradigm. It is characterized by differentiation of new models of adaptation strategies depending on factors of sustainable development and reducing vulnerability based on terminal value orientations.

Implementation of national and municipal programs maintains major trends in employment of local population: use of labour resources from outside the region for employment at large industrial enterprises; employment at the "grey" labour market that concentrates around economically developed social sectors including services; increasing number of requirements from regional and municipal authorities resulted in transition of business to the informal employment sector to optimize expenditure and survive in the market.

The identified criteria for social evaluation of labour adaptation of region's economically active population fall into two groups. The quantitative indicators are as follows:

1. General demographic indices (total population, persons; urban population, \%; population of working age, persons; economically active population, persons).

2 . The state of the recorded labour market (recorded unemployment, \%; average length of unemployment, month).

The qualitative indicators are: 
1. Education (the number of people with higher and postgraduate education, persons; with vocational education, persons; with secondary education, persons).

2. Morbidity and mortality (morbidity, per 1,000 individuals; first diagnosed occupational diseases, per 1,000 individuals of working age; mortality at working age, per 1,000 individuals of working age).

Problems of employment in the Arctic region of Yakutia are investigated in the context of sustainable development of the Arctic. Sociological surveys were conducted in the areas inhabited by minor indigenous people of the North. They revealed main challenges faced by young people in the market-driven labour relations, their view of priorities, standards, and rules of working life.

The studies on young people's challenges in society implemented through grants, involving the author of this paper, have been used to adjust youth policy and to study how younger generation of Yakutia's aboriginal community constructs social reality in employment.

The interviews with representatives of industrial companies demonstrate that new technologies are used to communicate with potential employees; investments are shifted towards creating databases of potential recruits (external personnel reserve) and social network communities.

\section{Acknowledgement}

The study was done with a support of the state assignment of the Yakut Scientific Center SB RAS "The Republic of Sakha (Yakutia) and great challenges: social well-being, mobility, and adaptation strategies" 02972021-0029, reference number 121031300008-7.

\section{References}

1. K. Grint, The sociology of work. An introduction (The Polity Press \& Blackwell Publishing, 2003)

2. T. Hiyama, H. Takakura, Global warming and human: nature dimension in Northern Eurasia (Springer, 2016)

3. H. Takakura, Arctic pastoralist Sakha. Ethnography of evolution and microadaptation in Siberia (Trans Pacific Press, 2015)

4. J. Larsen, G. Fondahl, eds., Arctic human development report. Regional processes and global linkages (TemaNord, 2014)

5. Z.T. Golenkova et al., Social inequality of Russian regions (Institute of Sociology RAS, 2017)

6. Y.V. Popkov et al., Ethno-social processes and ethnic policy in Siberian regions (SB RAS Publishing, 2015)

7. Y.V. Popkov, V.G. Kostyk, eds., Socio-cultural approach to regulating interaction of ethnic groups (Novosibirsk, Manuscript, 2013)

8. N.Y. Zamyatina, A.N. Pilyasov, Russian Arctic: towards new understanding of development (URSS, 2018)
9. A.N. Pilyasov, And the last will become the first: Northern rimland on the way to knowledge economy (URSS, 2015)

10. S.M. Baisheva, H. Transb. St. Univ. 12, 11 (2017)

11. S.M. Baisheva, T.N. Konstantinova, L.Y. Pisareva, Theor. Probl. Polit. Stud. 5A, 286 (2018)

12. Stat. Coll. Socio-economic conditions of areas of traditional habitat and traditional economy of indigenous peoples of RF in RS(Y) for 2012-2017, 14/466, 68 (2018) 